\title{
POST-WAR FORESTRY PROBLEMS OF THE PULP AND PAPER INDUSTRY
}

\author{
By V. E. JoHNson \\ Woodlands Manager, Canadian International Paper Company, Montreal, P.2. \\ $\mathrm{T}$ \\ HE GROWTH of the Pulp and Paper Industry in Canada has been one \\ of rapid expansion not always based, however, on sound principles. \\ Today looking to the future and benefitting by past mistakes, the Indus \\ try has, it appears to me, an opportunity for expansion limited only by our \\ vision and resourcefulness.
}

One of the principles which we have always recognized of greatest importance, and still do, in the development of the use of our forests, is accessible and economic raw material. In the earlier days of expansion the forests were relatively close to mills and settled areas, but the last twenty-five or thirty years have wrought great changes in this respect. It is not uncommon now to harvest forest materials two hundred or more miles from the mill, and we look to the future cutting of our woods products which would be considered uneconomical if judged by present standards. Between now and when we actually start operating these areas we must make sure that they are safeguarded by a plan of Forest Protection which will assure us of a crop to be harvested.

In capital invested the pulp and paper business outranks all others in Canada. Therefore, it has a great responsibility and a tremendous stake in the post-war development of this country. The component parts of the Industry are so scattered that the effect of prosperity or depression is felt from the great cities to the backwoods settiement. Hardly a community in eastern Canada continues its peaceful existence without in some way being affected by the production of pulp and paper. The nearer we go to the colonization stage the greater the contact with pulpwood. The Industry's products are essential and have every chance of expansion both in volume and form. Other businesses, including Government or the military services as we know them today, cannot function without paper products.

It is common knowledge that Pulps are used for such important items as explosives, plastics, substitutes for metal, rayon for tires, parachutes.

Paper Board is used in containers for shell cases, ammunition, gun barrels, machine parts, blood plasma, food and medical supplies.

Building Board is used for barracks, hospitals, munition works, substitute for lumber. 
Paper other than newsprint is used for towels, printing of Victory Bonds, War Savings Certificates, maps, charts, blueprints, etc. books.

Other papers are required for pamphlets, text books, technical books, school

Newsprint, of course, has its own important mission, and that is the dissemination of essential news both at home and abroad.

The essential need of pulp and paper products during wartime is tremendous. The public, however, are too prone to think that this forest industry is merely a producer of newsprint, whereas the figures of consumption indicate that newsprint only consumes approximately 40 per cent of the wood used in the Pulp and Paper Industry.

Today the wood equivalent which could be manufactured annually by existing pulp and paper mills in Canada is roughly $7,800,000$ cords, principally Spruce and Fir though large volumes of other species are tumed into pulp and paper products.

In addition to the wood equivalent used by Canadian Industry, there is a demand from other countries for great quantities of pulpwood. Undoubtedly the United States alone could use and would purchase in excess of 2,000,000 cords of wood if it were available.

The requirements for the lumber industry represent four to five billion f.b.m. - the equivalent of eight to ten million cords of wood. A similar quantity is required for fuel consumption. The total thus represented of thirty million cords of forest products is a challenge to management, and especially foresters, to see that the forest areas continue to produce this amount of wood and perhaps more. Obviously the reason we are not harvesting wood today to this extent is due to the shortage of man power.

It is recognized that under normal conditions there is sufficient man power in Canada to harvest this volume of wood and it is one of the greatest factors in Canada's economic life. Therefore, we must protect what we have, and make the necessary plans to absorb the personnel from the armed forces and war industries at the conclusion of hostilities, so that we can not only maintain our present pace but be prepared to accelerate.

You are all familiar with the rapid growth and expansion of the United States industrial life during the period 1910-1930, and there seems no reason why Canada cannot at this time follow the same trend. We have the man power, ingenuity and technical knowledge. There are vast quantities of power and raw materials available. Our job is to make the best use of them.

When you consider that newsprint alone annually brings to Canada foreign exchange in excess of $\$ 150,000,000$. you can see the relative importance of this great industry. When you add to this all the other forest products, it is easy to realize how great a factor we are in the world of industry.

The Pulp and Paper Business is the largest single industry employer of labor in Canada, providing in peace time a direct livelihood for over 500,000 people. 
Statistics tell us that only the Soviet Republics and Brazil have greater forest possibilities than Canada. If we are alive to our opportunities we can maintain the position of Industry with our excellent forest resources.

Recognition by the Government and the public of the important position of the forest industry resulted in the appointment of a. Committee for the studying of Post-War Reconstruction and Rehabilitation. Following this appointment a Sub-Committee was appointed on Conservation and Develop. ment of Natural Resources under the Chairmanship of Dr. R. C. Wallace, President of Queen's University.

This Committee viewed the natural resources not only of the forest itself, but those allied interdependent and intermingled assets which cannot be overlooked in the final analysis.

At the request of the Government that Committee submitted to the Hon. Mackenzie King, in September, a report of its findings. In its deliberation the Committee learned of the inadequate statistics, inventories a vailable, and lack of legislation and fundamental tabulated facts required for thorough understanding of the forest's effect on Canadian life. The Report of the Forestry Section on Forests and Forest Industries has not been released to Industry nor made public.

In order that Dr. Wallace's Committee could obtain co-operation from those more closely allied with the forests and whose responsibility it is to manage and operate these resources, it became neecssary to have provincial committees established to report their ideas on the type of work that could best be done to provide work at the conclusion of hostilities. Whether it be for returned men, or those from war industries, or those who did not necessarily take part in such industries, it is. essential that plans be available to take up the slack. It is obvious that forest industries can and will absorb a good proportion of this demand, but to prevent periods of non-employment it is important that constructive plans be ready and approved so that when those in authority decide that projects wholly or partially Government financed are necessary to maintain the proper level of economic life in Canada no delay will be encountered. Surely the results of the thinking among all these groups will result in a constructive plan for the welfare of Canada and the Canadian people.

The first consideration in our talking of post-war projects with respect to natural resources appears to be the necessity for constructing roads. The location of these roads will provide first, and above all, protection of the forest. Following this the prime motive is to make the forest accessible to operations. With such a basic plan established and construction well advanced, there will follow a re-allocation of harvesting of forest products. It is expected as well that a large number of tourists will take advantage of this. Sportsmen will welcome the opportunity of getting into these new areas. Thus we become involved in a complete new outlook on the potentialities of the forest. Many provincial programs have already been completed.

In order to proceed successfully, we must have the interest and backing of a thoroughly educated public. We cannot continue to keep the people of 
this country from the great outdoors. The development needed for forest lands involves much more than the actual harvesting of timber. After we have taken the necessary steps toward safeguarding our forests we must then consider in our management plans the great value of the forest for sporting and tourist purposes. One of the greatest attractions to the public and the medium through which we can achieve greater public interest is the making accessible of the back country so that people may fish and hunt and see our northern forest lands.

Before many of these things can be done, we must have preparatory measures such as Federal legislation providing the establishment of an Authority who will determine the needs and who will decide the procedure of carrying out the details. Once the Federal Government provides itself with proper authorization, it then becomes necessary to work through the Provinces. The Provinces then in turn must re-distribute the Authority and place the actual details in the hands of Industry, or of other groups, so that the jobs may be carried to final conclusion.

Today we do not have the staff of trained personnel for carrying on these jobs, regardless of how willing the Industry or Government may be in providing aid in the way of personnel.

We know that finances can be made available, and the establishment of our program becomes a job for the members of your Association and your associates in Government and Industry.

Your Association published in 1943 a thoroughly adequate and commend. able statement of forest policy. This policy recognizes the fundamental requirements of forestry in its many phases. A wider distribution and expanded publication of your recommendations can only result in bettering Canada's forest position. As I proceed with my discussion I shall touch upon many of the items referred to in your program. I must, however, say that the two basic principles, are first, adequate forest protection, and second, adequate forest management. Under those headings will probably come the greater number of all your suggestions, and these two are the subjects for which we can and should expect support from all Governments and the public.

I might mention at this time that L'Association Forestiere Quebecoise and the Canadian Forestry Association have likewise published statements on forest policy. There are no conflicts between these or other policies designed for the protection and management of Canada's forests. The objective is the same. We must, in the course of our thinking and planning, develop means whereby these policies can become a recognized part of every. day life and thinking for our forests.

The main objectives requiring study and adequate planning should be considered from a standpoint of those, first, which can be carried out immediately, and second, which require longer term planning for conservation and utilization of natural resources. The first group may be itemized as follows. 


\section{Forest Protection}

Serious thought should be given to this subject, especially along the lines of greater security of our forest resources. How can we attain more efficient protection against fire, and particularly during the period of extra hazardous weather conditions? The training of men along the lines of organization in emergencies, and in the principles of fire fighting, is very necessary and to my mind offers one of the greatest steps toward the advancement of more efficient fire control.

Forest Entomology and Pathology are a part of this forest protection. Lessons learned in recent Spruce Sawfly epidemics have paved the way for better control of similar attacks. Plans for more effective forest protection should be considered as a permanent feature, and to carry out these plans we need coroperation and financial assistance from government sources. Many of the subjects following are also direct contributions to Forest Protection. Closely allied to Forest Protection and directly affecting it are programs for road and telephone line construction.

\section{Management}

The aims of forest management are to obtain the maximum results from forest areas in the production and growth of the forest and the fullest possible utilization of their products. Our first basic need in management is greater accessibility to forest areas and thus enable operators to reduce forest losses. This can be accomplished largely by the building of truck roads and such roads would also serve as permanent features in forest utilization.

\section{StafF}

Under this heading personnel may be obtained to some measure from Industry and government departments. However, pre-training of the men who will act in a supervisory capacity on the jobs allocated under this program is necessary. We might well consider apprenticeship schemes through cooperation of the Department of Labour with forest industries. You are familiar with the Civilian Conservation Corps camps established in the U.S., and the National Forestry Program in Canada, the principle of which may well be considered for the training of our youth as they become of employment age.

\section{Preparation of Adequate Maps and Inventories}

- Obviously the best way to obtain a basis for this is through a well organ. ized program of aerial photography. Many areas of our forests are not suitably mapped and, therefore, it will be of great advantage to establish facilities for the reproduction of the necessary maps for use in carrying out any projects recommended.

\section{EQUIPMENT}

We have all seen the rapid adaptation of the tractor and bulldozer equip. ment. This development has been one of the most significant in the woods operations in the last twenty years. Ranked with this heavy equipment the simple development and adaptation of the bucksaw give keen competition for first place. 
I am not prepared to predict the type of equipment we should use or how it should be adapted to our operations, but it seems quite reasonable to expect vastly increased efficiency from the equipment used by the military services. In addition to this we should continue our studies and adaptation of portable saws, portable slashers, hydraulic barkers, all of which can readily aid in undertaking all-year-round operations. The development of a portable barker would greatly facilitate production of barked woods, thus avoiding contamination of streams with the refuse. To some extent this would eliminate heavy drum barking equipment now in use at the mills.

6. MarKeting

The United Kingdom and the United States are the greatest importers of forest products. It is quite possible that a corresponding market may result in South America or even in China. Certainly immediately after the war we can expect an accelerated demand for our exportable forest materials. The continued prosperity of forest industries is wholly dependent on these export markets and they in turn must be maintained and developed because continued prosperity is essential to Canada's wellbeing.

The intrinsic qualities of Canadian woods are as good as those of any other country. Our problem is cost of production and the improvement of the quality of our market products. Reorganization of the mills to utilize all raw products available from the forest would not only be effective in producing new commodities but would reduce waste and stabilize the In. dustry. As a partial example of this I might cite the Gatineau mills of the Canadian International Paper Company where today you will find the same management producing newsprint, high grade sulphite, building board and masonite. All that is required to complete this set-up is a reasonable sized sawmill. Thus one mill unit would be handling all types of softwood products from the forest, with distinct possibilities for handling a quantity of hardwoods. Within this unit no waste whatsoever results. The bark is consumed as fuel and the sawdust goes into the manufacturing process.

Successful business and, therefore, successful industry is based on the balance sheets. We know that we have forest products of the right species and of the proper quality; we have a population with the right characteristics and aptitudes; therefore, a properly developed market for multiple products can be built and maintained.

Long Term Planning will include the following subjects.

1. The Combined Inventory of Assets

For the Pulp and Paper Industry, such assets include pulpwood but intermingled with and affecting forest operations are the future development of water power, mines, colonization, attractions for tourists and sportsmen.

2. Soll SuRveys and Land Use

A properly defined knowledge of the soil would determine those areas which should remain in forests. It would, as well, determine the marginal areas of now so-called farming lands which should be returned to the production of forest products. A stabilized policy in this respect would be of great advantage in determining our long term forest policy. 
From the soil surveys, and dependent upon them, can be determined the proper use of the soil, whether it be for growing softwoods, hardwood for lumber or fuel, maple for sugar orchards, grazing,or farm products.

\section{RESEARCH}

With all due respect to the extensive work now being done by the Forest Products Laboratories and The National Research Council, I believe that we should endeavour to have their work extended on forest products and, as well, there should be research laboratories established in different parts of the country to meet local requirements and provide development for the local species of forest products.

\section{Land Tenure and Forest Reserves}

In many instances where timber licences are issued for only a short term the incentive for development is curbed by the insecurity of the operator's lease. Longer periods of tenure, such as fifty years, would provide an incentive for planning for not only today's needs but for a second crop. Such a plan could provide a permanent forest and a continued supply. The establishment of a pulp and paper mill is of a permanent character and is entitled to the assurance of a continued supply of raw materials.

\section{WiLd Life}

Our most appealing feature of the forest, for the greatest number of people, is our fish and game. Through these media we can solicit the goodwill and aid of sportsmen, not only of Canada but of the world. We can also use this feature as an aid in attracting tourists, who bring wealth to the country, and as a source of recreation for our own people.

Fish and game can be managed and can be grown as well as you manage your own garden and grow your own vegetables. I know of successful results in growing our native trout, which showed that after the first year these fish will, under proper conditions, grow to the extent of a pound per year. Large scale experiments under way show that the use of chemical fertilizer will improve the growth of this species by 40 per cent in a single summer. It is true that biological studies of the waters need to be made and proper planning and execution arranged so that we can get the best results. With our innumerable waters in Canada it is only a question of management and development to produce sufficient game fish for the enjoyment of every potential angler in the country.

Successful transplanting of wild life is readily possible as witnessed by the rapid expansion of the pheasant and Hungarian partridge particularly in the west. Here again the question of food is of vital importance but it can be arranged with results as attractive as those already definitely established for our game fish.

For many years, sportsmen and biologists alike have studied the salmon. We have gained a great deal of knowledge and now know how to increase this species. Under this subject I should point out to you who will have a hand in building management plans, that the large number of fishermen 
in this country are keenly interested in the improvement of fishing and there will be pressure by these groups for adequate fishways and control of pollution in all of our streams. Therefore, do not overlook these subjects which are of prime importance to a large body of the public and, therefore, deserving of consideration.

To me, fish and game are as much a part of Forest Management as the forest itself. True, they are a by'product-but what an attractive one and what a remunerative one to the country.

This development of wild life as a by-product is of more value to Canada and its people than to Industry. Therefore, if Industry is willing to do its share in developing this natural resource, the Government and the public must contribute their part: the Government by enforcing the adequate laws already on the statute books and the public by obeying these laws and co. operating with forest management.

\section{Watershed Protection}

We are all thoroughly familiar with what happens when heavy rainstorms or a quick thaw in the winter or spring occur. Tremendous damage is caused by flood waters, particularly in those areas which have been denuded of their forest stands. By proper reforestation and building of dams for storage, this annual or periodic damage can be prevented and those areasunder normal conditions-could produce a more pleasant and remunerative livelihood for the local people.

The Sub-Committee on Conservation carried out a very thorough study on the Ganaraska Watershed for this specific purpose. A definite recommendation for a similar study on the Rouge River has been made on the following basis:

1. Forest Resources,

a. Hardwood, Softwood Lumber,

b. Pulpwood,

c. Fuelwood,

2. Mining;

d. Miscellaneous Forest Products;

3. Farming;

4. Power;

5. Tourists;

6. Fishing and Hunting;

7. Winter Sports;

8. Watershed Protection.

Being accessible and having such varied interests, a survey of this area should appeal to the public and to the Government from the many angles mentioned above and it occurs to me that it might be an excellent study to be used as a guide for furthering the Province's post-war problems.

The purpose of the study would be:

1. To classify the land on the basis of land use, the criteria being the physical factors of soil, topography, stoniness, degree of erosion and the economic factors of intensity of use and/or productivity of a specific unit of land. Such a classification would be a basis of post- 
war planning.

2. To show the past, present and potential future use of land.

3. To obtain and analyse economic and social data that would tend to provide checks on the reliability of the classification established and to appraise the economic and social adjustments indicated, e.g., tenure, tax delinquency, mortgage indebtedness, municipal receipts and expenses, school administration, transportation services, rural electric power service, assessment values and associated data.

4. To analyse changes in growth of population and variations in the composition of the population.

5. Any other economic and social analysis essential in the development of a policy of more efficient use of land resources in the area.

6. To develop techniques essential in this type of research which are applicable to Eastern Canada.

\section{EdUCATION}

It is true that the place to start the education of our people is in the public schools and it has been evident recently that the school systems are interested in providing the fundamentals in the primary grades. We hope that this can be carried on and that our future generations will have a basic knowledge of our forest lands, as well as their relationship to industry and the prosperity of the country.

In order that we may place the natural resources of this country on a sound footing, we should undertake the education of the adult population as well. We-the Government and Industry-have for years frowned upon the public going to the forest. If this is the case, how can we expect our population to know about the forest? To me it is now time that we reverse our position and invite the public to go to the forest. If we want the public to follow industrial leadership we must provide it. We all recognize that there must be control and that these visitors to the forest areas must abide by established principles. With the return of automobiles and more guns, we can expect more people than ever before looking for the benefits of recreation in the great outdoors.

While many untrained men may be used in the forest industry, more effective work will result if practical training schools can be developed on such subjects as forest management, logging, cooking, silviculture, prospecting, guiding and wild life.

Knowledge and understanding bring respect and it is our job to see that the basic regulations and laws applying to forests 'and fish and game are respected, because it is a duty and there are sound reasons for such controls.

\section{FARM WOOD LOTS}

This subject requires an education plan for farmers with demonstrations of the potential profits from proper management of their lands. From this class of producers comes a substantial portion of the annual supply of pulp. 
wood and logs for our mills, as well as the bulk of fuelwood for the country. It is estimated that the industry pays from ten million to fifteen million dollars to farmers and settlers for pulpwood annually.

\section{Utilization}

Under the subject of "Marketing" I have referred to the fact that most of our mills are single-product units, and we all know that diversified products are necessary to provide more complete utilization of what we now consider as weed species. I am of the opinion that we should not necessarily change the type of species which grows in any particular forest area, but endeavour to make that species grow to its best, so that it may be utilized. Greater effort must be made in salvaging of slabs resulting from sawmill operations. It is common knowledge that there are hundreds of thousands of cords of slabs now going to waste from lumbering operations which can be used by the pulp and paper industries. It is true that during the war period this material is mostly being used as fuelwood, but under normal conditions here is a tremendous source of raw material for the pulp and paper industry. If we are able to solve the problem of making this ready for use economically, we have a steady source of a substantial amount of potential paper products. Here again a hydraulic barker, or some similar equipment, could be used to great advantage before the logs are sawn, thus making available the slabs free from bark which need only be dried out and then shipped to the mills.

Another phase which may be very useful is the possibility of making chips at the far away points and transporting this formerly waste material to the mills in a usable state.

The materials now wasted may well be a source of supply for fuel. Why should we not endeavour to salvage our waste wood products and thus conserve our coal supply? The use of charcoal has not been fully developed nor have we a proper program for its manufacture.

Following the war we shall continue the utilization of hardwood for veneers, plywoods, pulps and other marketable products.

\section{Silviculture}

Practices under this heading will undoubtedly mean increased costs when applied to Industry. There are many handicaps such as losses by fire, in security of holdings, tax burdens, and lack of trained personnel. Therefore, such work properly becomes a public enterprise and a government investment for future generations. There are many marketing problems that militate against a regular long-term plan of silviculture and years of full operation so frequently are unbalanced by terms of low mill production.

\section{Tourist Trade}

Here is a possibility for great development. It is understood that the Pulp and Paper Industry does not wish to become outfitters but if certain fundamental facilities are provided, the trade will grow by itself. Having provided the attractions which bring tourists, namely, beauty, solitude of the country, fish and game, adequate outfitters, and good roads, the returns to the nation should be enormous. 
As I have said before, our population has the proper characteristics to handle, manage and develop these natural resources but they need leadership, demonstration and training.

With respect to tourists and fish and game, we have a guide population in this country second to none and well worth while developing. Rough on the surface perhaps, lacking in the niceties of civilization, you'll find a rugged character, good companionship and a total lack of fear in the make-up of the real hunting and fishing guide. If he is properly trained he is one of the best sources of education for the layman.

\section{CONCLUSION}

I have tried to outline the assembled ideas of many people for the im. provement of forests and for the recognition of its proper value in Canadian economy. Today there is too much lack of appreciation by members of gov. ernment of the potentiality of forest products. It is the responsibility of Industry to demonstrate conclusively the great need for proper conservation, protection, and an intelligent development of our vast forests for the benefit of the Canadian people. You foresters, as men of experience, are a tremendous primary force in creating and developing the important position of forests to Industry and to Canada, and I urge you to do your full share in proving the value of a sound post-war program.

\section{APPENDIX A}

As a sample of what our Company considers a practical forest pro. gram with respect to post-war aims and benefit to the forest resources operated by us, we have submitted a program to the Post-War Reconstruction Committee of the Industry as follows:

Deferred Maintenance ...............\$ 488.000 .

Normal Improvements $\ldots \ldots \ldots \ldots \ldots \ldots .3,384,000$.

Major Improvements ............... 1,600,000.

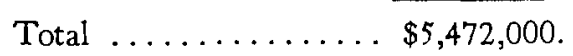

Deferred Maintenance because of non-availability of desired materials during the present period.

Normal Improvements are those normally undertaken for operating and maintenance economies.

Major Improvements are extensions and major improvements involving substantial capital expense.

\section{APPENDIX B}

As an interested limit holder and operator in Districts 5 and 6 of Quebec, we have worked out with other limit holders, represented by a local committee under the chairmanship of Mr. P. B. Bourget, a road system as shown on the posted map.

All of these projects are of benefit to the management and development 
of our forest resources. Industry cannot do them alone but they are ready to co-operate in their accomplishment.

Area about 28,000 sq. miles.

1,439 miles of first class truck roads $\ldots \ldots \ldots \$ 3,837,500$.

174 miles of improved roads ......... 173,000.

Annual up-keep ....... 40,325.

500 miles of second class roads ....... 400,000.

Total for roads ...... 4,450,825.

River Improvements .... 367,000 .

Bridges ........... 67,025 .

Grand Total ......... 4,884,850. 